\title{
Gossypium robinsonii, an Australian wild cotton species is an asymptomatic host of the cotton leaf curl disease pathogen complex
}

\author{
M. T. Azhar • I. Amin • Z. I. Anjum • S. Mansoor
}

Received: 17 August 2010 / Accepted: 9 February 2011 / Published online: 18 March 2011

(C) Australasian Plant Pathology Society Inc. 2011

\begin{abstract}
Three wild species of cotton (Gossypium sp.) of Australian origin being maintained in a living herbarium at Central Cotton Research Institute, Multan, Pakistan were screened for the presence of cotton leaf curl begomovirus components. The screening by PCR, rolling circle amplification and Southern hybridisation, showed that G. robinsonii is an asymptomatic carrier of components of the disease complex prevalent in Pakistan.). Only betasatellites associated with CLCuD was identified by PCR and RCA in G. nelsonii, and G. bickii and suggests that begomovirus levels were below detection limits.
\end{abstract}

Keywords Gossypium · Geminivirus · Cotton leaf curl disease $\cdot$ Betasatellite

Cotton leaf curl disease (CLCuD) is one of the most devastating diseases of cotton and causes severe damage to cotton in the Indian subcontinent. The causative agent of the disease has been characterised from Pakistan, India to Sudan (Mansoor et al. 2003; Idris et al. 2005; Sharma et al. 2005). CLCuD is caused by a complex belonging to the genus Begomovirus (family Geminiviridae). Geminiviruses are DNA viruses with circular single-stranded DNA genomes and have been divided into four genera based on

M. T. Azhar · I. Amin · S. Mansoor $(\square)$

Agricultural Biotechnology Division,

National Institute for Biotechnology and Genetic Engineering (NIBGE),

Jhang Road, P O Box 577, Faisalabad, Pakistan

e-mail: shahidmansoor7@gmail.com

\section{Z. I. Anjum}

Central Cotton Research Institute (CCRI),

Multan, Pakistan genome organisation and insect vectors. Whiteflytransmitted geminiviruses are classified in the genus Begomovirus and constitute the largest and economically the most important group (Briddon et al. 2000). The symptoms of CLCuD include leaf curling, vein thickening, stunting and small leaflet-like growth on underside of leaf called leaf enations (Briddon et al. 2001; Saeed et al. 2005; Qazi et al. 2007). At least seven distinct begomoviruses are known to occur on cotton and interact with a DNA betasatellite named Cotton leaf curl Multan betasatellite (CLCuMB). CLCuMB is essential for the development of disease symptoms in cotton (Mansoor et al. 2003). The disease has not been reported from Australia to Americas. However, the recent spread of whitefly biotypes and the introduction of Tomato yellow leaf curl virus from Middle East into Americas to Australia (Polston et al., 1999) shows that human activity is spreading viruses to geographical locations where it was not found earlier. The findings that Tomato leaf curl virus from Australia interacts with CLCuMB under experimental conditions suggest that $\mathrm{CLCuD}$ is a potential threat to cotton cultivation in Australia (Alberter et al. 2004; Saeed, 2010).

Cotton belongs to genus Gossypium, which is comprised of $\sim 50$ species including both wild and cultivated species. Of these, 45 are diploid and five are allotetraploid in nature (Fryxell, 1979), and these wild species are divided into eight different genome from A through $\mathrm{G}$ to $\mathrm{K}$. There are four cultivated species of cotton; each species has a separate centre of origin. G. hirsutum (allotetraploid, AD1), G. barbadense (allotetraploid, AD2), G. arboreum (diploid, A2) and G. herbaceum (diploid, A1) originated from South Mexico, South America (Peru), Indian subcontinent to South Africa, respectively. The three wild diploid species $G$. nelsonii, G. robinsonii and G. bickii, belonging to genome $\mathrm{G}, \mathrm{C}_{2}$ and $\mathrm{G}_{1}$ respectively, originated in Australia. 
Due to their potential as a source of useful genes, the wild species are used in different breeding programs for the improvement of cultivated cotton (Mehetre et al. 2004). Wild species of cotton are being maintained in a living herbarium at Central Cotton Research Institute (CCRI), Multan Pakistan under natural conditions and are being used in interspecific crosses. These species have been maintained for the last four decades and are exposed to $\mathrm{CLCuD}$. The present study was carried out to confirm the presence and identity of cotton leaf curl disease components in wild species of Australian origin being maintained in the herbarium.

Fresh leaf tissues of available wild diploid Gossypium species of Australian origin, namely, G. bickii, G. nelsonii and $G$. robinsonii were collected from CCRI, Multan, Pakistan. Total DNA was isolated following the CTAB method (Doyle and Doyle 1990). Betasatellite group-specific degenerate primers $\beta 01$ and $\beta 02$ (Briddon et al. 2001) were used to amplify a $\sim 1,400$ bp fragment. For G. bickii, the resultant PCR product was cloned into the $\mathrm{pTZ57R/T}$ vector (Fermentas) as per manufacturer's instructions. Recombinant E. coli colonies were selected using antibiotics and screened for plasmids with desirable inserts by restriction digest using $K p n \mathrm{I}$ restriction endonuclease. Sequencing products were resolved commercially (Macrogen, Korea). Sequence information was stored, assembled and analysed using the Lasergene sequence analysis package (DNAStar Inc., Madison, WI, USA). Sequence alignments were produced using CLUSTAL X (Thompson et al. 1997). Phylogenetic analyses were conducted using the neighbor-joining and bootstrap options of PHYLIP (V. 3.6) and phylogenetic dendrogram viewed and manipulated using TREEVIEW (Page 1996).

The genomic DNA of these wild species was also tested for the presence of the circular genomic components of begomoviruses using rolling circle amplification (RCA) as reported earlier from our lab (Nahid et al. 2008). Finally, Southern hybridization was also performed for the detection of begomoviruses and CLCuMB in wild diploid species of Australian origin described above. For Southern hybridization, the DNA A and betasatellite was amplified and probed with non-radio-labeled digoxigenin (DIG) kit (Roche, Germany).

In the present study, the available wild species of cotton originating from Australia were screened for the presence or absence of begomoviruses and betasatellites. The available wild diploid species originating from Australia were asymptomatic for $\mathrm{CLCuD}$. A series of diagnostic tests were carried out for the presence or absence of begomoviruses. The $1,400 \mathrm{bp}$ PCR product from the $\beta 01 / \beta 02$ betasatellite primer amplification showed the presence of begomoviruses betasatellites in G. bickii, G. nelsonii and G. robinsonii (Table 1). The circular molecules of begomoviruses were also detected
Table 1 The summary of detection of cotton leaf curl disease complex components by molecular methods in wild cotton species grown in herbarium at CCRI

\begin{tabular}{llll}
\hline $\begin{array}{l}\text { Name of } \\
\text { species }\end{array}$ & $\begin{array}{l}\text { RCA } \\
\text { amplification }\end{array}$ & $\begin{array}{l}\text { PCR } \\
\text { amplification } \\
\text { of betasatellite }\end{array}$ & Southern hybridisation \\
\hline G. bickii & + & + & $\begin{array}{c}\text {-(betasatellite), }- \\
\text { (DNA A) }\end{array}$ \\
G. nelsonii & - & + & $\begin{array}{c}\text {-(betasatellite) },- \\
\text { (DNA A) }\end{array}$ \\
G. robinsonii + & + & + & (betasatellite),+ \\
& & & (DNA A) \\
\hline
\end{tabular}
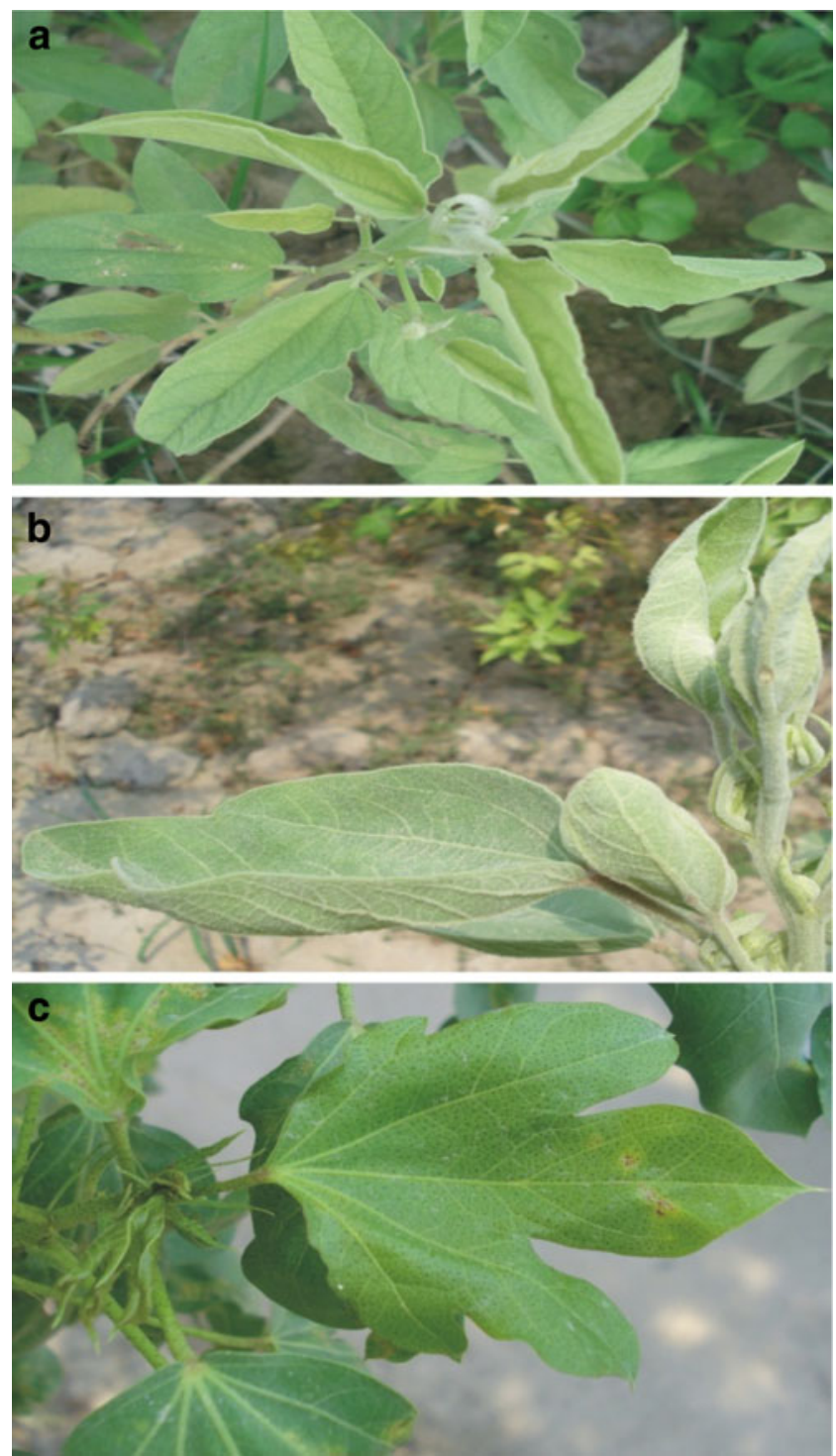

Fig. 1 Asymptomatic diploid, wild species of Gossypium originated in Australia. Panel a represents G. bickii, Panel b represents $G$. nelsonii and Panel c represents G. robinsonii collected from CCRI, Multan, Pakistan 
by $\phi 29$ DNA polymerase in the three Australian cotton species. Southern hybridization was also carried out for the detection of DNA-A and CLCuMB and detected both $\mathrm{CLCuD}$ components only in G. robinsonii. Our repeated efforts were unable to confirm the presence of begomovirus in G. bickii, or G. nelsonii by Southern hybridization and therefore we are unable to confirm them as carriers of CLCuD components.
To further confirm the identity of the betasatellite components, the PCR product obtained from G. bickii was cloned and sequenced (GenBank: AM712315). Sequence analysis showed the CLCuMB-[PK:T Beta11:07] isolated from $G$. bickii was of 1,351 bp in nucleotide length, encodes $\beta C 1$ protein of 118 amino acids and showed $99 \%$ DNA sequence identity to CLCuMB. The phylogenetic tree showed that CLCuMB-[PK:T Beta11:07] isolated from

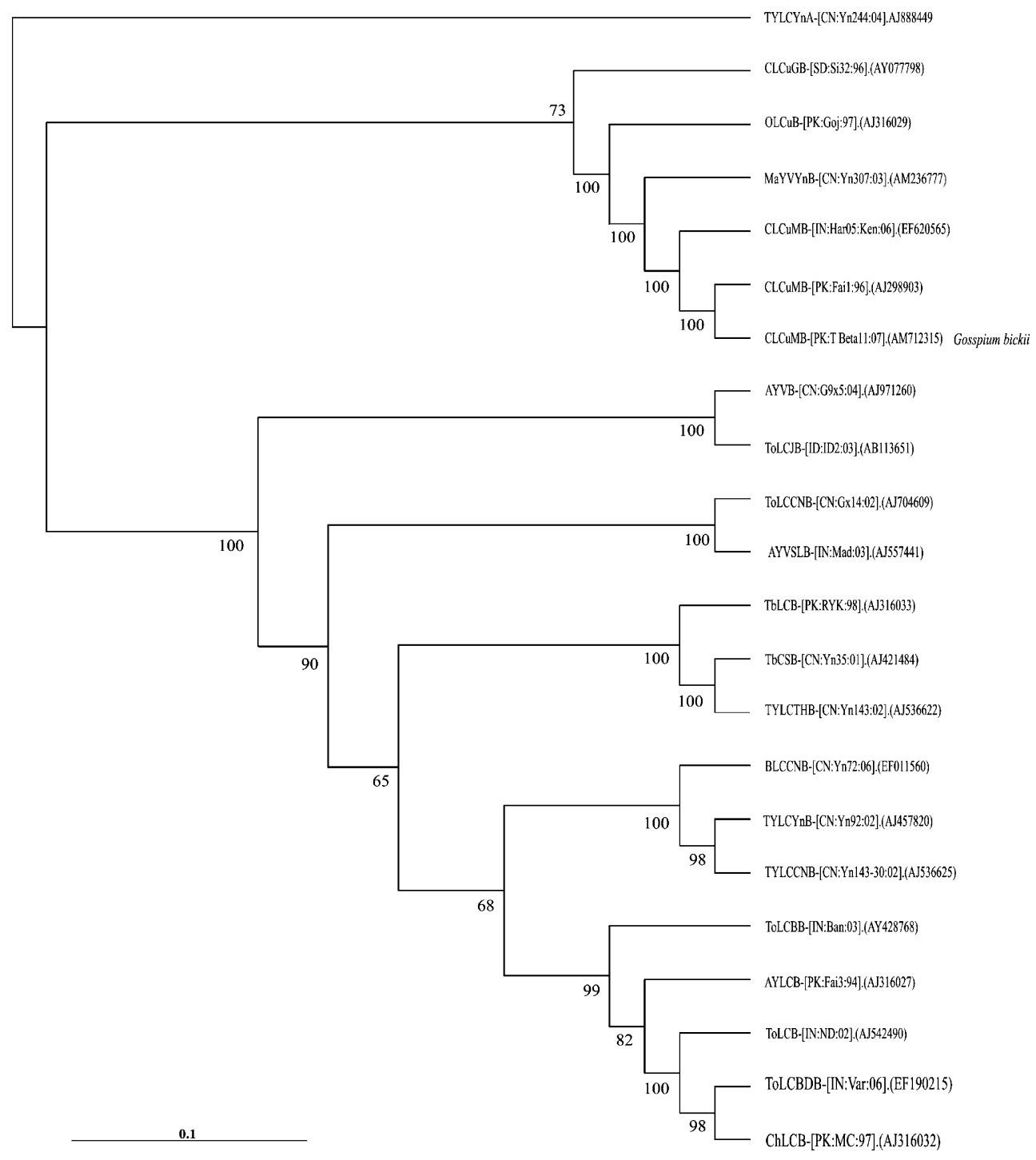

Fig. 2 Neighbor-joining tree of nucleotide sequences of betasatellite cloned from Gossypium bickii with available betasatellites associated with begomoviruses. The betasatellites used are Ageratum yellow vein Sri Lanka betasatellite (AYVSLB), Ageratum yellow vein betasatellite (AYVB), Ageratum yellow leaf curl betasatellite (AYLCB), Chilli leaf curl betasatellite (ChLCB), Cotton leaf curl Gezira betasatellite (CLCuGB), Cotton leaf curl Multan betasatellite (CLCuMB) Malvastrum yellow vein Yunan betasatellite (MaYVYnB), Okra leaf curl betasatellite $(\mathrm{OLCuB})$, Sida yellow mosaic China betasatellite (SiYMCNB), Tobacco curly shoot betasatellite (TbCSB), Tomato leaf curl Bangladesh betasatellite (ToLCBDB), Bean leaf curl China betasatellite (BLCCNB), Tomato yellow leaf curl Yunan betasatellite (TYLCYnB), Tomato leaf curl Bangalore betasatellite (ToLCBB), Tomato leaf curl China betasatellite (ToLCCNB), Tomato yellow leaf curl China betasatellite (TYLCCNB), Tomato yellow leaf curl Thailand betasatellite (TYLCTHB), Tomato leaf curl Java betasatellite (ToLCJB), based on alignment using Clustal X. The tree is rooted on Tomato yellow leaf curl Yunan alphasatellite- [CN:Yn244:04] (AJ888449), an unrelated sequence of a similar size. The numbers at each node are the percentage of bootstrap confidence values (1000 replicates). The database accession number is given in each case 
G. bickii was evolutionarily related with CLCuMB (CLCuMB-[IN:Har05:Ken:06]; EF620565) (Fig. 2). The phylogenetic tree supports the isolated betasatellite from wild cotton species ( $G$. bickii) clustered with other betasatellites isolated from Malvacous hosts as reported earlier (Briddon et al., 2003). Malvastrum yellow vein Yunan betasatellite (MaYVYnB-[CN:Yn307:03]; AM236777) is another related betasatellite (Fig. 2).

Our results show that G. robinsonii, a wild species of genus Gossypium of Australian origin is an asymptomatic host of CLCuD in herbarium at CCRI, Multan, Pakistan (Figs. 1 and 2). Only betasatellites associated with CLCuD was identified by PCR and RCA in G. nelsonii, and G. bickii and therefore the begomoviruses were below the detection levels. Cotton is the world's premier natural fiber for textile manufacture and a significant agricultural commodity in many countries including Australia. It is therefore imperative to monitor symptomatic and asymptomatic carriers of the virus in different parts of the world.

Acknowledgements MTA was supported by a $\mathrm{PhD}$ grant from "Higher Education Commission", Government of Pakistan. The research was supported by a research grant under Pak-USA project between NIBGE (PI Dr. Shahid Mansoor) and Donald Danforth Plant Science Center, St. Louis, Missouri, USA (PI Dr. Claude M Fauquet).

\section{References}

Alberter B, Rezaian MA, Jeske H (2004) Replicative intermediates of Tomato leaf curl virus and its satellite DNAs. Virology 331:441448

Briddon RW, Bull SE, Amin I, Idris AM, Mansoor S, Bedford ID, Dhawan P, Rishi N, Siwatch SS, Abdel-Salam AM, Brown JK, Zafar Y, Markham PG (2003) Diversity of DNA $\beta$ : a satellite molecule associated with some monopartite begomoviruses. Virology 312:106-121

Briddon RW, Mansoor S, Bedford ID, Pinner MS, Markham PG (2000) Clones of cotton leaf curl geminivirus induce symptoms atypical of cotton leaf curl disease. Virus Genes 20:19-26
Briddon RW, Mansoor S, Bedford ID, Pinner MS, Saunders K, Stanley J, Zafar Y, Malik KA, Markham PG (2001) Identification of DNA components required for induction of cotton leaf curl disease. Virology 285:234-243

Doyle JJ, Doyle JL (1990) Isolation of plant DNA from fresh tissue. Focus 12:13-15

Fryxell PA (1979) A natural history of cotton tribe. Texas A \& M University Press, College Station and London

Idris AM, Briddon RW, Bull SE, Brown JK (2005) Cotton leaf curl Gezira virus-satellite DNAs represent a divergent, geographically isolated Nile Basin lineage: predictive identification of a satDNA REP-binding motif. Virus Res 109:19-32

Mansoor S, Briddon RW, Bull SE, Bedford ID, Bashir A, Hussain M, Saeed M, Zafar Y, Malik KA, Fauquet CM, Markham PG (2003) Cotton leaf curl disease is associated with multiple monopartite begomoviruses supported by single DNA $\beta$. Arch Virol 148:1969-1986

Mehetre SS, Patil SC, Pawar SV, Pardedhi SU, Shinde GC, Aher AR (2004) Ovulo embryo cultured hybrid between amphi-diploid (Gossypium arboreum $\times$ Gossypium anomalum) and Gossypium hirsutum. Curr Sci 87:286-289

Nahid N, Amin I, Mansoor S, Rybicki EP, van der Walt E, Briddon RW (2008) Two dicot-infecting mastreviruses (family Geminiviridae) occur in Pakistan. Arch Virol 153:1441-1451

Page RDM (1996) TREEVIEW: an application to display phylogenetic trees on personal computer. Comput Appl Biosci 12:357-358

Polston JE, McGovern RJ, Brown LG (1999) Introduction of tomato yellow leaf curl virus in Florida and implications for the spread of this and other geminiviruses of tomato. Plant Dis 83:984-988

Qazi J, Amin I, Mansoor S, Iqbal J, Briddon RW (2007) Contribution of the satellite encoded gene $\beta C 1$ to cotton leaf curl disease symptoms. Virus Res 128:135-139

Saeed M, Behjatnia SAA, Mansoor S, Zafar Y, Hasnain S, Rezaian MA (2005) A single complementary-sense transcript of a geminiviral DNA $\beta$ satellite is determinant of pathogenicity. Mol Plant-Microbe Interact 18:7-14

Saeed M (2010) Tomato leaf curl virus and cotton leaf curl Multan betasatellite can cause mild transient symptoms in cotton. Australas Plant Dis Notes 5:58-60

Sharma P, Rishi N, Malathi VG (2005) Molecular cloning of coat protein gene of an Indian cotton leaf curl virus (CLCuV-HS2) isolate and its phylogenetic relationship with others members of Geminiviridae. Virus Genes 30:85-91

Thompson JD, Gibson TJ, Plewniak F, Jeanmougin F, Higgins DG (1997) The Clustal_X windows interface; flexible strategies for multiple sequence alignment aided by quality analysis tools. Nucleic Acids Res 25:4876-4882 